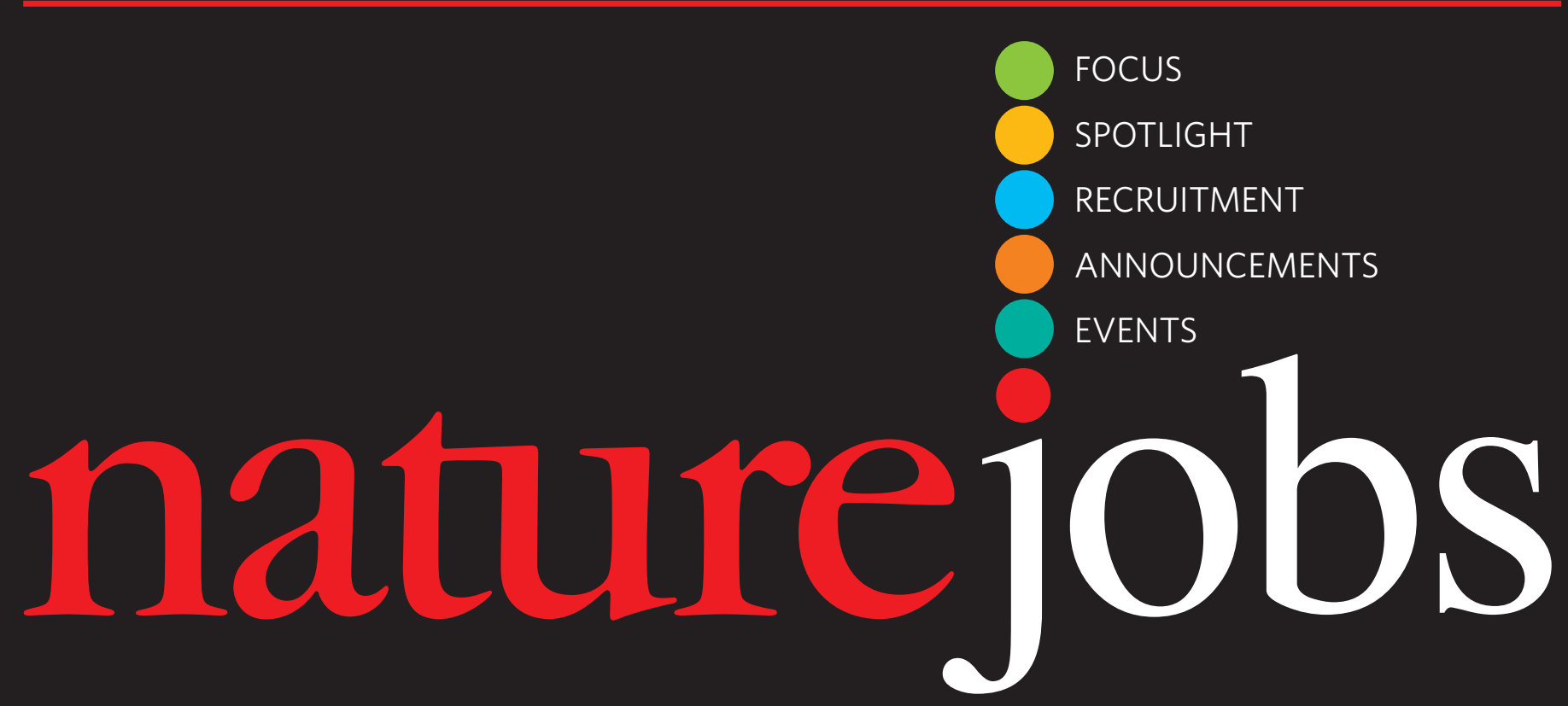

\section{Turning the tables}

Imagine that China dominated the research world, with the best labs, the most funding and the highest publication record. With little chance for advancement at home, young scientists from the United States and Europe would pour into the country. Because China's research growth has been so rapid, it can't produce enough home-grown scientists. So it welcomes the Westerners - after a fashion.

Western graduate students and postdocs coming into China are expected to teach in Chinese, and if they can't communicate with their Chinese students and colleagues, they lose their funding, their job and their visa.

Westerners would consider such a scenario unacceptable, and with good reason. But that's the situation for many Chinese graduate students and postdocs working and studying in the Western world. The story of Xuemei Han, a Yale graduate student who almost got sent back to China because she was considered "not in good academic standing", despite passing her preliminary exams, is a case in point (see Nature 438, 278-279; 2005). Hundreds of Chinese students rallied to her cause because, even if they had been successful in the United States, they felt that their presence in the country was tenuous, owing to many circumstances beyond their control. Han eventually managed to secure her grant, found another adviser and kept her visa.

Ideally, Han's predicament will do more than illustrate inequity and will result in better conditions for the foreign scientists much of the Western world depends on. It should rally principal investigators to find ways to make foreign graduate students and postdocs more secure. Solutions could range from more support in language lessons to assurances that visas won't be cancelled if they switch advisers or universities. After all, Western scientists would ask for the same treatment if the tables were turned.

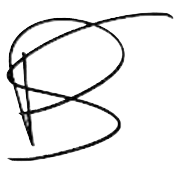

\section{Paul Smaglik, Naturejobs editor}

CONTACTS

Publisher: Ben Crowe

Editor: Paul Smaglik

Assistant Editor: Corie Lok

US Head Office, New York

345 Park Avenue South, 10th Floor,

New York, NY 10010-1707

Tel: +1 8009897718

Fax: +18009897103

e-mail: naturejobs@natureny.com

US Sales Manager/Corporations: Peter Bless

Classified Sales Representatives

Tel: +1800989 7718
New York/Pennsylvania/

Latin America: Andrew Bennie

Midwest USA/Maryland/

NIH: Wade Tucker

East USA/Canada:

Janine Taormina

San Francisco Office

Classified Sales Representative:

Michaela Bjorkman

West USA/West Corp. Canada

225 Bush Street, Suite 1453

San Francisco, CA 94104

Tel: +14157813803

Fax: +1 4157813805

e-mail:m.bjorkman@naturesf.com
European Head Office, London

The Macmillan Building,

4 Crinan Street,

London N19XW, UK

Tel: +44 (0) 2078434961

Fax: +44 (0) 2078434996

e-mail: naturejobs@nature.com

Naturejobs Sales Director: Nevin Bayoumi (4978) European Sales Manager: Andy Douglas (4975)

Advertising Production Manager: Billie Franklin To send materials use London address above. Tel: +44 (0) 2078434814

Fax: +44 (0) 2078434996

e-mail: naturejobs@nature.com
Naturejobs web development: Tom Hancock Naturejobs online production: Niamh Shields

European Satellite Office

Patrick Phelan

e-mail:p.phelan@nature.com

Japan Head Office, Tokyo

Chiyoda Building,

2-37 Ichigayatamachi,

Shinjuku-ku,

Tokyo 162-0843

Tel: +81332678751

Fax: +81332678746

Asia-Pacific Sales Director: Rinoko Asami

e-mail: r.asami@naturejpn.com 